\title{
THE EFFECTS OF READING HABIT AND GRAMMAR MASTERY TOWARDS STUDENT'S READING COMPREHENSION
}

\author{
Zennytra Rachmativani ${ }^{1}$, \\ Supeno ${ }^{2}$, \\ Universitas Indraprasta PGRI, Jakarta \\ e-mail: zennyt.tivani@gmail.com ${ }^{1}$ \\ e-mail: supeno@unindra.ac.id ${ }^{2}$
}

\begin{abstract}
The aim of this research are to find: 1) The effects of Reading Habit and Grammar Mastery jointly Towards Student's Reading Comprehension. 2) The Effects of Reading Habit Towards Student's Reading Comprehension. 3) TheEffects of Grammar Mastery Towards Student's Reading Comprehension. The method used is survey method. The instruments were used multiple choice and questioner. Total samples of this research followed by 75 students with a cluster simple random technique. The result showed: 1)There are significant effects of reading habit and grammar mastery jointly towards the student's reading comprehension. This is proved by the value of sig. $0.000<0.05$ and $F_{\text {observed }}=52.564$. 2) There is a significant effect of reading habit towards student's reading comprehension. This is proved by the This is proved by the value of sig. $0.000<0.05$ and $t_{\text {observed }}=7.620$. 3) There is significant effect of the grammar mastery towards student's reading comprehension significantly. This is proved by the This is proved by the value of sig. $0.000<0.05$ and $\mathrm{t}_{\text {observed }}=6.100$.
\end{abstract}

Keywords: reading habit; grammar mastery; reading comprehension

\section{Introduction}

In this era globalization English is the second language. Even though, English is being taught to children at primary level until university level. Students are strictly made to learn in English when they are in school. In learning English, there are four aspects of skills that the students are required to master. They are listening, speaking, reading and writing. Now days, reading comprehension became very important in education fields; students need to be exercised and trained in order to have good reading skill. According to Van den Broek \& Espin (as cited in Moore, 2014) that "reading comprehension is a complex interaction among automatic and strategic cognitive process that enables the reader to create a mental representation of the text." It means that reading comprehension can build communication from the text and the reader can make their perception. In fact, in the higher level, reading is not comprehended the written symbols only, but reading comprehension is comprehend, accepting, rejecting, and comparing a text. At all levels of education, reading comprehension becomes the priority that must be master's in students' learning.

Reading has become the need for many people. Reading should be a habit for everyone. Habit form through repetition of behavior in a specific context (Lally, van Jaarsveld, Potts, \& Wardle, 2010). Habit is not only a huge part of our everyday life but also one of the most influential governing factors of our existence. Your actions, your responses, the decisions you make, your life are all largely dictated by your habits. Reading can be a habit if learners realize that it has many benefits for themselves in improving their language skills, enriching their vocabulary, developing their thoughts and ideas, and supporting their achievement. It can make the learners active, creative, and critical in learning. Reading habit therefore is compulsory and represents a requirement that cannot be bargained.

English learners do need to learn the basic grammatical rules of English as well as the practice of good communication skills in the language. Grammar mastery plays a great role in determining the success of foreign language learning. Khansir (2015) indicated that grammar is plays a vital role in language teaching. It 
means grammar is the important thing that teacher must understand deeply. Even though the teacher must find appropriate methods to make the students do not feel bored when learning about grammar. If the students lack of understanding in grammar especially about tenses such as; simple present tense, present continuous tense, simple past tense and simple past continuous tense. They will be afraid and unconfident to reveal something to others.

Based on the writer teaching experience she often found there were some factors influenced student's reading comprehension a few of them were reading habit and grammar mastery. There are several factors that make the problems happen. The first, the students are lazy to read. As we know that the students don't like to read because they thought that reading such a boring activity. The students preferred to read for pleasure, while their module or academic materials. It seems that the students rule out the importance of reading textbooks. The second, the present of smartphone make the students are autism with their own world. They can explore what they want and need easily. Moreover they find out the answers of their homework from it. So they do not need read their tasks book or module. The third, they do not pay attention when the teacher explains the lesson. They prefer chatting and having fun with their friends than listening to the explanation from their teacher. They can ignore the advice from the teacher. As the result they don't understand about the material which is given by teacher. The fourth, their parents give less attention in forming their childrens' habit of reading. Based on the problems happened the writer decide to investigate whether or not the effects of reading habit and grammar mastery towards student's reading comprehension.

\section{Method}

This study emphasizes on the effect of reading habit and grammar mastery towards student's reading comprehension. It means that there are two independent variables and one dependent variable; variable X1 as the first independent variable (reading habit) and variable X2 as the second independent variable (grammar mastery) which have interconnected and influenced the variable $Y$ as the dependent variable (student's reading comprehension). The method used is a survey with multiple correlation technique. The research is done of 75 students of the Class IX students of Mts.Al-Hasaniyah, Mts. Mathla'ul Anwar and Mts.Babussalam Kabupaten Tangerang. This research consists of 3 variables. Namely, the reading habit $\left(\mathrm{X}_{1}\right)$, grammar mastery $\left(\mathrm{X}_{2}\right)$ as the independent variable, and student's reading comprehension $(\mathrm{Y})$ as dependent variable. The assumption test for regression parameter test of the data research is done by normality test through Kolmogorov Smirnov method, and regression model linearity test.

\section{Results and Discussion}

In analysing the data it was purposed on the hypothesis test that was started by the research data description of three variables in the form of data analysis using descriptive statistics such as finding mean, mode, median, standard deviation, and inferential statistics is to describe the effect of the variable is used by multiple regressions. The assumption test for regression parameter test of the data research is done by normality test through Kolmogorov Smirnov method, and regression model linearity test. The research is done of 75 students of the Class IX students of Mts.Al-Hasaniyah, Mts. Mathla'ul Anwar and Mts.Babussalam Kabupaten Tangerang. This research consists of 3 variables. Namely, the reading habit $\left(\mathrm{X}_{1}\right)$, grammar mastery $\left(\mathrm{X}_{2}\right)$ as the independent variable, and student's reading comprehension $(\mathrm{Y})$ as dependent variable. For testing requirements analysis the researcher used Kolmogorov Smirnov as method of normality test. Based on the calculation in SPSS 20.0 the result of analysis table shows that the hypothesis test which states the residual distribution in this regression analysis follows a normal distribution. This is indicated by the value $\mathrm{Z}=0.731$ and sig. $=0.658>0,05$. This means that assumptions or requirements for regression analysis are fulfilled.

Linearity is done to determine the technique in regression analysis whether the independent variable (X1 and X2) and the dependent variable (Y) are linear. This linearity test uses SPSS 20.0 calculation. The result from (X1) towards (Y) is Based on the table 4.6 above, it obtained calculation result Deviation from Linearity with fo $=1.481$ and sig. $=0.121>0.05$. In the other words, we can say that the regression line which indicates the effect of reading habit $(\mathrm{X} 1)$ towards student's reading comprehension $(\mathrm{Y})$ is liner. Besides that, the result of $(\mathrm{X} 2)$ towards $(\mathrm{Y})$ is Based on the table 4.8 above, it obtained calculation results Deviation from Linearity with fo $=0.976$ and sig. $=0.515>0.05$. in other words, we can say that the regression line 


\section{INFERENCE: Journal of English Language Teaching}

Vol. 3, No. 2, August - November 2020

p-ISSN: 2615-8671

e-ISSN: 2615-868X

which indicates the effect of grammar mastery (X2) towards student's reading comprehension (Y) is linear. However, the new data is valid for the purpose of testing the hypothesis if the data has a normal distribution assumption and the data are linear. The recapitulations of the entire test can be seen in the set of following tables:

Table 1. Recapitulations Result of Multiple Correlation Coefficients of the Effects of Reading Habit (X1) and Grammar Mastery (X2) towards Student's Reading Comprehension (Y)

\section{Model Summary b}

\begin{tabular}{|l|r|r|r|r|}
\hline Model & R & R Square & Adjusted R Square & $\begin{array}{c}\text { Std. Error of the } \\
\text { Estimate }\end{array}$ \\
\hline 1 & $.770^{\mathrm{a}}$ & .594 & .582 & 6.093 \\
\hline
\end{tabular}

a. Predictors: (Constant), Grammar Mastery (X2), Reading Habit (X1)

b. Dependent Variable: Student's Reading Comprehension (Y)

The correlation test results between reading habit and grammar mastery towards student's reading comprehension correlation value is 0.770 . If consulted by $r_{\text {table }}$ value with $5 \%$ level of error $(95 \%$ confidence level) $n=75$ in product moment value $r_{\text {table }}$ is 0.224 . The result $r_{\text {observed }}(0.770)>r_{\text {table }}(0.224) . H_{o}$ is rejected and $\mathrm{H}_{\mathrm{a}}$ is accepted. The correlation coefficient (0.770) is positive and has a strong correlation level at the coefficient interval 0.60-0.799. This means that there is a significant effect of reading habit and grammar mastery towards student's reading comprehension. From Table 1 is shown that the R Square value is 0.594 or $59.4 \%$. It means that reading habit and grammar mastery can contribute to reading comprehension by $59.4 \%$ and $40.6 \%$ are still influenced by other factors.

Table 2. Recapitulation Result of Coefficient Regression Significant Test of the Effects of Reading Habit (X1), Grammar Mastery (X2) towards Student's Reading Comprehension (Y)

\begin{tabular}{|ll|r|r|r|r|r|}
\hline \multicolumn{1}{|l|}{ Model } & & Sum of Squares & \multicolumn{1}{|c|}{ Df } & Mean Square & \multicolumn{1}{c|}{ F } & Sig. \\
\hline 1 & Regression & 3903.133 & 2 & 1951.566 & 52.564 & $.000^{\mathbf{a}}$ \\
& Residual & 2673.187 & 72 & 37.128 & & \\
& Total & 6576.320 & 74 & & & \\
\hline
\end{tabular}

a. Predictors: (Constant), Grammar Mastery (X2), Reading Habit (X1)

b. Dependent Variable: Student's Reading Comprehension (Y)

Meanwhile, the simultaneous test in this study was used to see the effects of two independent variables on the dependent variable. This simultaneous test is carried out by the F test. The hypothesis will be accepted if $F_{\text {observed }}>F_{\text {table }}$ or alpha (0.05) with the denominator $\mathrm{dk}$ and the numerator dk point $\mathrm{n}=75$ is 1.47 indicating that the calculated $\mathrm{F}$ test obtained a value of 52.564, while $F_{\text {table }}(1.47)$ or by Sig. value $=0.000<0.05$, because $F_{\text {observed }}$ is greater than $F_{\text {table. }}$. It can be stated that reading habit and grammar mastery jointly have significant effects towards reading comprehension.

Table 3. The Recapitulation Result for Coefficient Regression and Significant of Partial Test of the Effects of Reading Habit $\left(\mathrm{X}_{1}\right)$ and Grammar Mastery $\left(\mathrm{X}_{2}\right)$ towards student's Reading Comprehension (Y)

\begin{tabular}{|c|c|c|c|c|c|}
\hline \multirow[b]{2}{*}{ Model } & \multicolumn{2}{|c|}{ Unstandardized Coefficients } & \multirow{2}{*}{$\begin{array}{c}\text { Standardized } \\
\text { Coefficients } \\
\text { Beta }\end{array}$} & \multirow[b]{2}{*}{$\mathrm{t}$} & \multirow[b]{2}{*}{ Sig. } \\
\hline & $\mathrm{B}$ & Std. Error & & & \\
\hline (Constant) & -9.460 & 7.922 & & -1.194 & .236 \\
\hline Reading Habit (X1) & .536 & .070 & .575 & 7.620 & .000 \\
\hline Grammar Mastery (X2) & .535 & .088 & .460 & 6.100 & .000 \\
\hline
\end{tabular}

a. Dependent Variable: Student's Reading Comprehension (Y) 
Partial Test result ( $\mathrm{t}$ test) that the first variable is obtained by the t-test value is 7.620 and when compared to the $t$-table value (the provision of $\mathrm{df} n-2=73$ is 1.666). It turns out that $t_{\text {observed }}$ value (7.620) $>$ $\mathrm{t}_{\text {table }}(1,666)$, while the Sig. value is 0.000 it means the Sig.value $<0.05 . \mathrm{H}_{\mathrm{o}}$ is rejected and $\mathrm{H}_{\mathrm{a}}$ is accepted. Thus, the result of this hypothesis test proved that reading habit significantly affect towards student's reading comprehension.

Partial test result (t test) in the second variable is obtained by the value of $t_{\text {observed }} 6.100$ and when compared with the value of $t_{\text {table }}$ (determination df $n-2=73$ is 1.666 ). It proved by $t_{\text {observed }}$ value $(6.100)>$ $\mathrm{t}_{\text {table }}$ (1.666). The Sig. value is $0.000<0.05 . \mathrm{H}_{0}$ is rejected and $\mathrm{H}_{\mathrm{a}}$ is accepted. Thus, the result of this hypothesis test proved that grammar mastery significantly affects towards student's reading comprehension.

\section{Conclusions}

Some conclusions of this research can be presented as follows:

1. There are significant effects of reading habit and grammar mastery jointly towards student's reading comprehension of the eighth grade at Private Junior High School in Kabupaten Tangerang. That is proved by the value of sig. $0.000<0.05$ and $\mathrm{F}_{\text {observed }}=52.564$.

2. There is a significant effect of reading habit towards student's reading comprehension of the eighth grade at Private Junior High School in Kabupaten Tangerang. That is proved by the value of Sig. $0.000<0.05$ and $\mathrm{t}_{\text {observed }}=7.620$.

3. There is a significant effect of grammar mastery towards student's reading comprehension of the eighth grade at Private Junior High School in Kabupaten Tangerang. That is proved by the value of Sig. $0.000<0.05$ and $t_{\text {observed }}=6.100$.

\section{References}

Lally, P., van Jaarsveld, C. H. M., Potts, H. W. W., \& Wardle, J. (2010). How are habits formed: Modelling habit formation in the real world. European Journal of Social Psychology, 40(6), 998-1009. https://doi.org/https://doi.org/10.1002/ejsp.674

Moore, A. L. (2014). A Research Review of Cognitive Skills, Strategies and Interventions for Reading Comprehension. Diambil dari http://downloads.learningrx.com/reading-comprehension-researchpaper.pdf

Khansir, A. A., \& Dehghani, N. (2015). The Impact of Extensive Reading on Grammatical Mastery. Theory and practice in Language Studies, 150. 